\title{
MAKAM CHABIB UMAR BIN YUSUF AL-MAGRIBI DI BEDUGUL Sejarah, Dampak Sosial Ekonomi dan Potensi sebagai Sumber Belajar Sejarah di SMA
}

\author{
Nur Minah
}

\begin{abstract}
Abstrak
Tujuan penelitian ini adalah untuk mengetahui (1) Sejarah pendirian makam Chabib Umar Bin Yusuf AlMagribi di Desa Candikuning, (2) Dampak sosial ekonomi bagi masyarakat Desa Candikuning, (3) Potensi makam Chabib Umar Bin Yusuf Al- Magribi di Desa Candikuning, Bedugul dapat digunakan sebagai sumber belajar sejarah di SMA. Penelitian ini merupakan penelitian sejarah, sehingga langkah-langkah yang dilakukan adalah (1) Heuristik; (2) Kritik Sumber; (3) Interpretasi; (4) Historiografi. Hasil penelitian ini menunjukkan bahwa, (1) Sejarah pendirian makam Chabib Umar Bin Yusuf Al-Magribi dengan ditemukannya lokasi makam yang terletak di atas bukit bedugul Desa Candikuning pada tahun 1940-an yang disinyalir merupakan makam seorang tokoh penyebar agama Islam yang berasal dari Timur Tengah. (2) Dampak sosial ekonomi dari Makam Chabib Umar Bin Yusuf Al- Magribi bagi masyarakat di Desa Candikuning, Bedugul adalah dampak mengenai mata pencaharian masyarakat sekitar makam, pendapatan masyarakat sekitar makam, serta interaksi sosial yang terjadi di dalam masyarakat. (3) Makam Chabib Umar Bin Yusuf Al-Magribi mengandung nilai historis sebagai salah satu tokoh penyebar agama Islam di Bali dan merupakan salah satu wali pitu yang dapat dijadikan sebagai sumber belajar sejarah lokal di SMA.
\end{abstract}

Kata Kunci: Sejarah, Dampak Sosial Ekonomi, dan Sebagai Sumber Belajar Sejarah

\begin{abstract}
The purpose of this study was to find out (1) History of the chabib Umar Bin Yusuf Al-Magribi tomb in the village of Candikuning, (2) Socio economic impact for the community in the village of Candikuning, (3) Potential of the tomb of Chabib Umar Bin Yusuf Al-Magribi in the village of Candikuning, Bedugul can be used as a source of historical learning in high school. This research is a historical research, so the steps taken are (1) Heuristics; (2) Source Criticism; (3) Interpretation; (4) Historiography. The results of this study indicate that, (1) The history of the establlishment of the Chabib Umar Bin Yusuf Al-Magribi tomb with the discovery of the location of the tomb located on the hill of the village of Candikuning Bedugul in the 1940s which was allegedly the tomb of a prominent Muslim propagator from the Middle East. (2) The socio economic impact of the Chabib Umar Bin Yusuf Al-Magribi tomb for the community in the village of Candikuning, Bedugul is the impact on the livelihoods of the people around the tomb, as well as the social interactions that occur within the community. (3) The tomb of Chabib Umar Bin Yusuf Al-Magribi containts historical value as one of the leaders of the spread of Islam in Bali and is one of the guardians who can be used as a source of learning local history in high school.
\end{abstract}

Keywords: History, Socio-Economic impact, and as a Source of Learning History 


\section{Pendahuluan}

Makam adalah sebuah tempat untuk mengubur jenazah atau menggali lubang untuk orang yang meninggal dunia baik itu para raja, pahlawan, tokoh masyarakat dan juga orang biasa. Sedangkan makam dalam Kamus Besar Indonesia (1990: 503) mengandung dua makna, yaitu: (1) Mengantarkan jenazah ke perkuburan, (2) kata benda yang artinya tempat tinggal atau kediaman. Menurut Soekmono (dalam Mulyani, 2013) dijelaskan bahwa makam merupakan wujud dari tiga kebudayaan yaitu gagasan, aktifitas, dan artefak. Makam berupa hasil aktifitas perbuatan manusia yang dapat diraba, dilihat dan bahkan didokumentasikan. Makam biasanya diabadikan dengan bangunan yang terbuat dari batu yang disebut jirat atau kijing. Bagi orang-orang penting, di atas jirat biasanya didirikan rumah yang disebut cangkub atau kubah.

Makam-makam yang dapat ditemui selain berbentuk gumbukan tanah juga terdapat makam-makam kuno yang berbentuk seperti sarkofagus, peti mayat, kubur batu, dan punden-berundak. Sarkofagus adalah peti jenazah yang terbuat dari batu atau peti batu untuk menguburkan orang-orang yang berasal dari golongan tertentu (Sagimun, 1987:39). Makam juga berfungsi sebagai penghormatan para leluhur seperti halnya masyarakat Indonesia yang masih memegang teguh kepercayaan tersebut bahwa orang yang telah meninggal akan memberi barokahnya. Apalagi orang-orang yang dianggap sakti dan mempunyai peran penting dalam masyarakat itu sendiri, orang tersebut apabila sudah meninggal, masyarakat menganggapnya masih terdapat karomah atau keistimewaan dari orang tersebut. Banyak orang yang melakukan ziarah kubur ketempat orang yang dianggap memiliki keistimewaan selama hidupnya.

Perpindahan orang Islam ke Bali umumnya mengikuti suatu pola yang selalu diawali oleh adanya suatu migran pelopor yang menempati areal tertentu (Atmaja, 2002). Pada masyarakat yang ada di Bali seperti di Kabupaten Klungkung, Jembrana,
Karangasem, Badung, Tabanan dan Bangli. Tetapi, hal yang berbeda terjadi di Kabupaten Buleleng para migran pionir yang datang ke Buleleng adalah prajurit kerajaan pada masa pemerintah Panji Sakti (1593-1600). Prajurit Islam ini ditempatkan di Desa Pegayaman yang bertugas membendung serangan yang dilakukan oleh kerajaan Mengwi. Prajurit inilah yang selanjutnya menjadi cikal-bakal terbentuknya Desa Pegayaman (Atmaja, 2002).

Adanya peningkatan jumlah penduduk muslim tidak dapat dilepaskan dari peran masyarakat Bali terutama yang beragama Hindu, mereka memberi tempat dan sangat toleran terhadap orang-orang Islam sehingga mereka memiliki persamaan untuk hidup di bali. Ini dapat dilihat dengan semakin banyaknya pemukiman Islam maupun penghuninya. Di samping itu pula perpindahan yang mereka lakukan adalah model migrasi berantai dengan mengajak sanak keluarga untuk ikut migrasi.

Meskipun sudah ada yang meneliti tentang makam belum ada yang mengkaji secara khusus tentang Makam Chabib Umar Bin Yusuf Al-Magribi, terutama mengenai potensinya sebagai sumber belajar sejarah di tingkat SMA. Banyak keunikan yang terdapat pada makam ini misalnya yang pertama, dilihat dari tempatnya yang berada di atas bukit Kebun Raya Bedugul dan merupakan makam dari orang yang menganut Agama Islam. Kedua, pengunjung yang datang ketempat ini bukan hanya umat Islam namun juga Umat Hindu dan Kristen. Seperti yang diketahui umat Islam merupakan umat yang memiliki tradisi ziarah kubur karena mereka percaya akan adanya kekuatan magis pada suatu makam, dalam ziarah kubur tersebut ada yang hanya sekedar mendoakan orang yang telah meninggal ataupun untuk memohon sesuatu. Kunjungan ke makam-makam orang yang mereka hormati hal tersebut dilakukan sesuai dengan kepercayaan atau keyakinan mereka. Ketiga, miskipun telah banyak yang datang ketempat ini namun masyarakat di sekitar lokasi belum semuanya mengetahui 
asal-usul atau sejarah pendirian Makam Chabib Umar Bin Yusuf Al-Magribi. Banyaknya keunikan yang terdapat di dalamnya sehingga menjadi menarik untuk diteliti lebih jauh.

Kurikulum pembelajaran sejarah yang ada di Indonesia menyangkut tentang makam dalam materi maupun buku-buku sejarah selama ini menjadi bahan yang asing untuk dikaji ataupun disampaikan di dalam kelas oleh guru sejarah. Sebagian besar buku-buku SMA khususnya kelas $\mathrm{X}$ yang hanya memuat materi yang berkaitan dengan peran wali songo dalam penyebaran Islam di Jawa tidak banyak yang mengkaji tentang peran wali pitu yang ada di Bali sebagai sumber bahan ajar.

Makam Chabib Umar Bin Yusuf AlMagribi dapat dikaitkan ke SK/KD Sejarah Indonesia Wajib di Sekolah Menengah Atas (SMA) kelas X pada Kurikulum 2013 yakni dalam Kompetensi Inti: Memahami, menerapkan, dan menganalisis pengetahuan faktual, konseptual, prosedural, dan berdasarkan rasa ingin tahunya tentang ilmu pengetahuan, teknologi, seni, budaya, dan humaniora dengan wawasan kemanusiaan, kebangsaan, kenegaraan, dan peradaban terkait penyebab fenomena dan kejadian, serta menerapkan pengetahuan prosedural pada bidang kajian yang spesifik sesuai dengan bakat dan minatnya untuk memecahkan masalah. Dengan Kompetensi Dasar 3.8 Menganalisis perkembangan kehidupan masyarakat, pemerintahan dan budaya pada masa kerajaan-kerajaan Islam di Indonesia serta menunjukkan contoh bukti-bukti yang masih berlaku pada kehidupan masyarakat Indonesia masa kini. 4.8 Menyajikan hasil penalaran dalam bentuk tulisan tentang nilainilai dan unsur budaya yang berkembang pada masa kerajaan Islam dan masih keberlanjutan dalam kehidupan bangsa Indonesia pada masa kini. Berdasarkan latar belakang masalah diatas, maka dapat diajukan dalam permasalahan yang dikaji adalah sebagai berikut (1) Bagaimana sejarah pendirian makam Chabib Umar Bin Yusuf Al- Magribi di Desa Candikuning, Bedugul?
Bagaimana dampak sosial ekonomi dari makam Chabib Umar Bin Yusuf Al- Magribi bagi masyarakat di Desa Candikuning, Bedugul? (3) Potensi apa saja dari makam Chabib Umar Bin Yusuf Al- Magribi di Desa Candikuning, Bedugul yang dapat dijadikan sebagai sumber belajar sejarah di SMA?. Dengan rumusan masalah di atas, maka tujuan yang ingin penulis capai dalam penelitian ini diantaranya (1) Untuk mengetahui sejarah pendirian makam Chabib Umar Bin Yusuf AlMagribi di Desa Candikuning, Bedugul (2) Untuk memahami dampak sosial ekonomi dari makam Chabib Umar Bin Yusuf Al- Magribi bagi masyarakat di Desa Candikuning, Bedugul (3) Untuk memahami potensi yang ada pada makam Chabib Umar Bin Yusuf AlMagribi di Desa Candikuning, Bedugul yang dapat dijadikan sebagai sumber belajar sejarah di SMA.

Kajian teori yang digunakan dalam penelitian ini menyangkut tentang (1) Teori strukturasi, (2) Sejarah pendirian makam, (3) Sumber belajar sejarah.

\section{Metode Penelitian}

Metode penelitian yang digunakan dalam penelitian adalah metode penelitian sejarah. Tahap-tahap penelitian ini meliputi : (1) Pengumpulan data (Heuristik), langkah pertama dalam heuristik ini adalah teknik observasi/study lapangan, setelah itu langkah kedua teknik wawancara, dan yang ketiga studi dokumentasi. (2) Kritik sumber, kritik yang dilakukan terdiri dari dua hal yaitu kritik ekstern dan kritik intern. (3) Interpretasi (analisis data). (4) Historiografi (penulisan sejarah).

\section{Pembahasan}

\section{Sejarah Pendirian Makam Chabib Umar}

Berdasarkan wawancara dengan juru kunci makam bapak Haji Norman (60 tahun), didapatkan informasi bahwa Makam Chabib Umar Bin Yusuf Al- Magribi adalah seorang tokoh pemimpin agama Islam. Chabib Umar Bin Yusuf Al- Magribi merupakan tokoh penyebar agama Islam di wilayah Desa 
Candikuning. Makam Chabib Umar Bin Yusuf Al-Magribi yang terletak di Desa Candikuning, Bedugul merupakan salah satu bagian dari makam Wali Pitu yang ada di Bali. Dimana Chabib Umar Bin Yusuf Al-Magribi ini seorang ahli tauhid yang berasal dari Lombok datang ke Bali dan tinggal menetap di atas Bukit Candikuning, Bedugul.

Kedatangan Chabib Umar Bin Yusuf AlMagribi di Pulau Bali tidak langsung menuju istana kerajaan. Ia lebih memilih tinggal di daerah Bukit Bedugul yang sangat indah. Karena beliau termasuk seorang ulama atau Wali Allah yang menganut paham Islam Sufi. Seperti Sunan Muria yang ada di Pulau Jawa. Chabib Umar Bin Yusuf Al- Magribi lebih suka menyendiri meninggalkan keramaian istana kerajaan Bali yang waktu itu seringkali melakukan peperangan sesama anggota keluarganya untuk memperebutkan tahta kerajaan. Beliau lebih memilih tinggal di Bukit Bedugul dan sekali-kali turun ke Danau Bedugul untuk menikmati keindahan alam.

Dalam melakukan dakwah, Chabib Umar

Bin Yusuf Al-Magribi lebih banyak memberikan contoh teladan kebaikan dalam kehidupan sehari-hari dari pada ceramah. Beliau masuk desa keluar desa membantu masyarakat yang membutuhkan pertolongan. Ia hidup dalam kehidupan meninggalkan duniawi yang berlebihan. Hidup menyendiri di atas Bukit Bedugul bersama santri-santrinya. Beliau menikmati dunia ini dengan rasa beryukur. Hidup damai hingga akhir hayat di makamkan di atas bukit tersebut.

Chabib Umar Bin Yusuf Al- Magribi merupakan wali yang masih memiliki darah keturunan dari Nabi Muhammad. Bila dilihat dari nama belakangnya Al Magribi berarti berasal dari Timur Tengah yang datang ke Bali untuk menyebarkan ajaran agama Islam. Namun belum diketahui apakah terdapat keturunan silsilah Chabib Umar Bin Yusuf Al- Magribi di Bali sebab chabib ini datang ke Bali tidak membawa seorang istri dan anak akan tetapi dia hanya membawa santrisantrinya untuk menyebarkan ajaran agama islam. Dapat dilihat dari paham yang anutnya yaitu paham sufi dimana seseorang tidaklah mendalami duniawi dan lebih mendekatkan diri kepada sang penciptanya (Hasil wawancara Haji Norman, 60 tahun).

Makam Chabib Umar Bin Yusuf AlMagribi berwujud empat batu nisan untuk dua makam yaitu makammnya Chabib Umar Umar Bin Yusuf Al-Magribi dan santrinya yang luasnya $4 \times 4 \mathrm{M}$. Hingga saat ini keberadaan keasliannya masih dipertahankan. Hanya saja disamping kanan kiri makam dibangun sebuah fasilitas untuk para peziarah yang datang dari jauh.

Pada setiap bulan Safar pada hari rabu terakhir (Jawa: rebo wekasan) dan bulan Sya'ban masyarakat setempat berbondongbondong naik ke bukit berziarah di makam Chabib Umar Bin Yusuf Al- Magribi. Hal ini untuk memperingati wafatnya dengan mengadakan do'a bersama. Selain itu juga masyarakat luar Desa Candikuning datang setiap tahun untuk berdo'a hingga sampai sekarang.

Hasil penelitian ini sesuai dengan yang diungkapkan oleh (Soekmono, $1981: 83$ ) yang mengungkapkan bahwa makam sendiri berasal dari bahasa Arab, yang berarti memendam, melupakan, memasukan, mengebumikan. Makam merupakan temlat kediaman yang terakhir dan yang abadi, disahkan pula untuk menjadi perumahan yang sesuai dengan orang yang dikubur dan dengan alam yang mudah berganti. Terutama makam para Raja, seperti istana saja layaknya. Seakan-akan makam itu disamakan dengan orangnya, lengkap dengan pembesar-pembesar pengiringnya yang terdekat, bersama-sama tinggal di dalam istana. Demikianlah maka makam merupakan suatu gugusan cungkub-cungkub dan jirat-jirat yang dikelompokkan menurut hubungan kekeluargaannya. Gugusan ini dibagi dalam berbagai halaman yang dipisahkan oleh tembok-tembok tetapi dihubungkan dengan gapura-gapura, sedangkan sebuah masjid menjadi pelengkapnya. 


\section{Dampak Sosial Ekonomi}

Dampak sosial ekonomi dari Makam Chabib Umar Bin Yusuf Al- Magribi bagi masyarakat Desa Candikuning, Bedugul. Dampak kehidupan sosial ekonomi masyarakat di kawasan Makam Chabib Umar Bin Yusuf Al- Magribi. Dampak sosial ekonomi yang dimaksud adalah dampak mengenai mata pencaharian masyarakat sekitar makam, peran pemerintah (desa), pendapatan masyarakat sekitar makam, pola konsumsi masyarakat, serta interaksi sosial yang terjadi di dalam masyarakat.

\section{Interaksi Sosial Masyarakat}

Perubahan kehidupan sosial ekonomi masyarakat dapat mengubah proses interaksi sosial yakni melalui kontak dan komunikasi secara langsung akan mempengaruhi pengembangan perekonomian masyarakat, sehingga pola interaksi sosial melalui kontak dan kominikasi akan sangat diperlukana untuk menjalin hubungan yang harmonis antara para pedagang masyarakat sekitar makam di kawasan Makam Chabib Umar Bin Yusuf AlMagribi bagi masyarakat Desa Candikuning. Sebagaimana hasil wawancara dengan kepala desa yaitu Bapak I Made Mudita

"Perubahan kehidupan sosial ekonomi masyarakat dapat mengubah proses interaksi sosial yakni dengan cara melalui jalinan komunikasi secara langsung dengan baik maka akan mempengaruhi pengembangan perekonomian masyarakat, sehingga pola interaksi sosial melalui jalinan komunikasi secara langsung dengan baik akan sangat diperlukan untuk membangun sebuah hubungan yang harmonis antara para pedagang masyarakat sekitar makam di kawasan Desa Candikuning".

(Wawancara, Mudita, 26/03/2019).

Data di atas juga didukung dengan hasil wawancara dengan Bapak Husen yang menyatakan bahwa :

"Perubahan kehidupan sosial ekonomi masyarakat di sekitar Makam Chabib Umar Bin Yusuf Al- Magribi dapat mengubah pola interaksi sosial dikalangan para pedagang baik pedagang yang merupakan penduduk asli dan penduduk pendatang, sehinggan dengan adanya kumunikasi yang baik membuat para pedagang ini bisa bekerjasama untuk memperlancar proses berdagangnya, seperti saling tukar menukar barang dagangan dan uang."

(Wawancara, Husen, 26/03/2019).

Berdasarkan hasil wawancara di atas perubahan kehidupan sosial ekonomi masyarakat di sekitar Makam Chabib Umar Bin Yusuf Al- Magribi dapat mengubah proses intraksi sosial dikalangan para pedagang, sehingga dengan adanya jalinan komunikasi membuat para pedagang bisa saling bekerjasama untuk membangun hubungan perdagangan yang baik dan lancar.

\section{Nilai-Nilai Sosial Masyarakat}

Nilai adalah konsepsi abstrak yang tidak dapat disentuh oleh panca indra yang dapat ditangkap hanya barang atau tingkah laku perwujudan dari nilai. Nilai merupakan realitas tapi bukanlah objek faktual bukan juga essensi dari objek. Nilai adalah kualitas yang tidak riil dan tidak ada melalui dirinya. Nilai butuh pengembangan untuk menyatakan eksistensi dari nilai tersebut.

Nilai bersifat praktis dan efektif dalam sikap dan tindakan manusia dan melembaga secara objektif didalam masyarakat, dalam bentuk sistem nilai. Sistem nilai ini menjadi aturan atau tatanan pandangan dan anggapan masyarakat yang digunakan sebagai pedoman dalam menilai sesuatu dan dalam mengendalikan serta memilih tingkah laku dalam kehidupan sehari-hari. Jadi sistem nilai merupakan akumulasi dari keseluruhan yang hidup ditengah masyarakat sebagai bentuk kearifan yang menjadi norma dalam intraksi sosial individu dan masyarakat. Adapun nilainilai sosial yang terjadi di dalam masyarakat Desa Candikuning sebagi berikut. 


\section{Nilai Gotong Royong}

Gotong royong adalah identitas nasional. Karenanya budaya gotong royong seharusnya terus dijaga supaya terus diamalkan dalam kehidupan sehari-hari. Gotong royong berarti mengangkat secara bersama-sama atau mengerjakan sesuatu secara bersama-sama. Gotong royong dapat dipahami pula sebagai bentuk partisifasi aktif setiap individu untuk ikut terlibat dalam memberi nilai positif dari setiap objek, permasalahan, atau kebutuhan orang-orang di sekelilingny. Partisifasi aktif tersebut dapat berupa bantuan yang berwujud materi, keuangan, tenaga fisik, mental spritual, keterampilan, sumbangan pikiran atau atau nasehat yang konstruktif, sampai hanya berdoa dengan Tuhan. Seperti yang diungkapkan oleh bapak Norman (60 tahun) bahwa :

"Nilai gotong royong ini sebenarnya sudah ada dari zaman dulu dan dimana pada saat pembangunan makam tidak hanya umat islam saja yang membangun namun ada juga umat lain yaitu umat hindu yang membatun dalam mengerjakan pembangunan makam ini. Jadi nilai gotong royong ini sangatlah penting dan disanalah kita bisa saling mengenal dan bisa berbaur antar sesama umat di Desa Candikuningtg ini."

(Hasil wawancara, Norman, 60 tahun).

\section{Dampak Ekonomi}

Salah satu dampak yang paling nyata terlihat dari pengembangan suatu objek wisata adalah perkembangan ekonomi. Keuntungan dari pengembangan industri pariwisata dalam bidang ekonomi adalah penciptaan lapangan pekerjaan, serta adanya kemungkinan bagi masyarakat di negara penerima wisatawan tersebut untuk meningkatkan tingkat pendapatan dan standar hidup mereka .

Dalam pelaksanaan kegiatan pariwisata tentu saja terjadi hubungan intraksi antara wisatawan dengan pelaku usaha wisata. Intraksi ini tentu saja menimbulkan dampak bagi para pelakunya, baik wisatawannya maupun pelaku usaha wisatanya. Dampak yang ditimbulkan dari kegiatan wisata dapat berupa dampak positif maupun dampak negatif sehingga bisa mempengaruhi kondisi sosial maupun ekonomi masyarakat pelaku usaha pariwisata tersebut. Akibat adanya kunjungan wisatawan ke daerah wisata tentu saja dapat dimanfaatkan masyarakat untuk mencari penghasilan dengan menyediakan atau menawarkan jasa akomodasi maupun yang berkaitan dengan kegiatan pariwisata. Dengan adanya intraksi ini maka masyarakat sebagai pelaku usaha pariwisata dapat memberi dampak positif yaitu dapat menciptakan atau memperoleh lapangan pekerjaan dari sektor pariwisata. Namun disisi lain dengan adanya kegiatan pariwisata tentu saja dapat menimbulkan dampak negatif, yaitu dapat menimbulkan atau terjadinya dampak gaya hidup maupun kebudayaan luar yang tidak sesuai di bawa oleh wisatawan dan berdampak pada masyarakat pelaku usaha pariwisata maupun masyarakat sekitar yang berintraksi dengan wisatawan. Terjadinya dampak baik positif maupun negatif sebagai akibat intraksi wisatawan dengan masyarakat pelaku wisata dan masyarakat sekitar obyek wisata tidak dapat dihindari lagi dampak yang ditimbulkan juga tidak semuanya berdampak langsung namun juga terdapat dampak secara tidak langsung yang dampaknya dapat dirasakan dalam jangka waktu tertentu. Tentu saja kesejahteraan masyarakat sebagai pelaku usaha atau yang menggantungkan mata pencahariannya dari kegiatan wisata di Makam Chabib Umar Bin Yusuf Al- Magribi dan snagat dipengaruhi kegiatan kepariwisataan tersebut.

Selain itu dampak yang ditimbulkan tentunya juga membawa masyarakat untuk beralih dari kegiatan pertanian ke sektor wisata. Walaupun tidak terlalu banyak yang terjun ke sektor pariwisata, namu apabila ini terus berlanjut tentunya akan membawa dampak negatif dengan meninggalkan sektor pertanian. Terlebih lagi beberapa lahan pertanian disekitar kawasan makam mulai beralih fungsi menjadi tempat restaurant maupun penginapan-penginapan. Hal ini akan berakibat buruk kedepannya apa bila hal ini 
terus berlanjut. Dalam hal ini diperlukan suatu kesadaran dalam menjaga alam disekitar kawasan Makam Chabib Umar Bin Yusuf AlMagribi agar nantinya tidak seluruh lahan pertanian beralih fungsi menjadi tempattempat penunjang obyek wisata, seperti penginapan-penginapan dan restaurant.

\section{Sumber Belajar Sejarah di MA Al- Irsyad}

Sejarah adalah mata pelajaran yang menanamkan pengetahuan, sikap, dan nilainilai mengenai proses perubahan dan perkembangan masyarakat Indonesia dan dunia dari masa lampau hingga kini. Pengajaran sejarah disekolah bertujuan agar siswa memperoleh kemampuan berfikir historis dan pemahaman sejarah. Sedangkan fungsi dari pembelajaran sejarah yaitu untuk menyadarkan siswa akan adanya proses perubahan dan perkembangan masyarakat dalam dimensi waktu dan untuk membangun perspektif serta kesadaran sejarah dalam menemukan, memahami, dan menjelaskan jati diri dari bangsa di masa lalu, masa kini, dan masa depan di tengah-tengah perubahan dunia (Agung \& Wahyuni, 2013 : 55-56).

Sumber belajar merupakan salah satu faktor penentu keberhasilan proses belajar mengajar di sekolah, selain guru, siswa, bahan ajar, dan media pembelajaran. Kurangnya pemanfaatan sumber belajar dalam kegiatan belajar mengajar dapat mengakibatkan siswa kurang kreatif dan menjadi terdiam. Sumber belajar dapat memberikan pengalaman langsung kepada siswas sehingga siswa mudah menerima materi pelajaran dan memberikan pengalaman kepada siswa contohnya menggunakan sumber belajar berupa lingkungan. Sumber belajar yang ada disekitar yakni lingkungan merupakan suatu sumber belajar yang nyata dan dapat dilihat secara langsung oleh siswa.

Selain teori dikelas dirasa membosankan dan materi sejarah juga sangat banyak sehingga membuat siswa bosan. Maka salah satu cara yang dapat ditempuh yakni dengan memanfaatkan sumber belajar berupa lingkungan yang ada disekitar sekolah.
Menurut hasil wawancara peneliti dengan Pak Ahmad Alfian yang menyatakan bahwa :

"Saya sebagai guru sejarah selama ini mengajar di kelas banyak menggunakan metode ceramah dan hanya berpatokan pada sumber berupa buku. Untuk sumber lainnya belum dapat Saya manfaatkan dalam proses pembelajaran, hanya saja di dalam kelas mengenai materi peninggalan perkembangan kebudayaan islam. Saya hanya memberikan berupa contohnya saja salah satu peninggalan yang ada di Candikuning khususnya makam tersebut."

(Wawancara, Ahmad Alfian, 26/03/2019).

Dari pendapat yang dilontarkan oleh guru sejarah di MA Al- Irsyad Candikuning, hal tersebut juga diperkuat dari hasil wawancara dengan seorang siswi di MA AlIrsyad yaitu Nisa Safitri yang menyatakan bahwa :

"Pada mata pelajaran sejarah khususnya materi Masuknya Islam Ke Indonesia, guru kebanyakan menjelaskan dengan metode ceramah yang membuat saya dan temanteman kebanyakan bosan dan hanya mendengarkan ceritanya saja. Guru juga dapat sedikit menyinggung tentang peninggalan-peninggalan kebudayaan Islam di Bali khususnya Makam Chabib Umar Bin Yusuf Al- Magribi sebagai salah satu contoh peninggalan kebudayaan masa Islam, akan tetapi juga belum sampai menceritakan secara rinci mengenai sejarah makam Chabib Umar Bin Yusuf Al- Magribi”.

(Wawancara, Nisa, 26/03/2019).

\section{Pendidikan Karakter}

Setiap adanya pembangunan makam tentunya akan menghasilkan nilai-nilai Pendidikan Sejarah Maupun Pendidikan Nilai Karakter baik dari segi bangunan makam maupun kegiatan yang terkandung di dalamnya yang dapat dipetik oleh masyarakat sekitar khususnya bagi peserta didik. Nilainilai karakter tersebut antara lain : 


\section{Nilai Religius}

Nilai religius seperti tindakan yang sifatnya memuja, menolong, bersedekah, beramal dengan hati yang ikhlas tanpa pamrih yang dijiwai oleh keagamaan tersirat di dalam perbuatan atau tindakan yang bersifat keagamaan, seperti melakukan ziarah ke makam Chabib Umar Bin Yusuf Al- Magribi. Nilai religius adalah dasar dari terbentuknya sebuah budaya religius, karena jika setiap orang tidak memiliki suatu kereligiusan dalam hidupnya maka mustahil dapat terbentuk suatu budaya religius (Hidayanti : 7). Sulityani (2017 : 8) juga menjelaskan bahwa religius adalah nilai karakter dalam hubungannya dengan Tuhan. Ia menunjukkan bahwa pikiran, perkataan, dan tindakan seseorang yang diupayakan selalu berdasarkan pada nilai-nilai ketuhanan dan/atau ajaran agamanya. Pusat Kurikulum 2013 juga menjelaskan bahwa nilai religius adalah sikap dan perilaku yang patuh dalam melaksanakan ajaran agama yang dianutnya, toleran terhadap pelaksanaan ibadah agama lain, dan hidup rukun dengan pemeluk agama lain. Nilai religus yang dapat diamati melalui proses mendoakan, membacakan ayat-ayat suci al- qur'an yang dilakukan oleh peziarah makam Chabib Umar Bin Yusuf Al- Magribi.

\section{Nilai Toleransi}

Manusia mulai mengenal hal baik yang dilakukan dalam masyarakat, dalam hidup bersama akan membawa kegembiraan dan kebahagian bagi semua orang. Kebiasaan melakukan perbuatan baik dan bertanggung jawab terhadap akibat yang timbul dari perbuatan yang dilakukan haruslah menjadi cerminan tingkah laku sehari-hari. Penerapan nilai toleransi sesama umat maupun umat lain sangatlah penting bagi kehidupan sehari-hari. Nilai toleransi yang terdapat di dalam makam Chabib Umar Bin Yusuf Al- Magribi dapat diamati pada saat para peziarah yang berziarah tidak hanya umat muslim namun dari umat lainpun ada yang datang berizarah yang tujuannya sama untuk melalukan ziarah religi. Disaat seperti itulah para peziarah saling menghormati dan menghargai tidak saling membedakan agama apa yang dianutnya.

\section{Nilai Disipilin}

Nilai pendidikan karakter ini menekankan pada tindakan yang menunjukkan perilaku tertib dan patuh pada berbagai ketentuan dan peraturan yang ada dalam kehidupan bernegara. Nilai ini tampak pada saat peziarah yang berziarah mengantri dan bergiliran masuk ke dalam makam untuk medoakan dan membacakan ayat-ayat suci al- qur'an yang bertujuan untuk menghindari timbulnya ketidak cocokan terhadap sesama peziarah yang berkunjung.

\section{Nilai Kerja Keras}

Perilaku yang menunjukkan upaya sungguh-sungguh dalam mengatasi berbagai hambatan guna menyelesaikan tugas dengan sebaik-baiknya. Dalam setiap kegiatan harus dilakukan dengan keja keras sehingga kita dapat menikmati hasil yang maksimal. Dalam pelaksanaan pembangunan makam Chabib Umar Bin Yusuf Al- Magribi terlihat adanya rasa kerja keras yang dilakukan oleh para penduduk guna untuk bisa menyelesaikan pembnagunan makam. Selain itu bisa dilihat dari letak makam yang sangat jauh dan tinggi sehingga sangat memerlukan tenaga yang maksimal dalam membawa bahan bangunan makam.

Hasil penelitian ini sesuai menurut Sanjaya (2006 : 172) mengemukakan bahwa sumber belajar adalah segala sesuatu yang dapat dimamfaatkan oleh siswa untuk mempelajari bahan dan pengalaman belajar yang disesuaikan dengan tujuan yang akan dicapainya. Dalam proses pembelajaran yang disesuaikan dengan perkembnagan pengetahuan dan teknologi khususnya teknologi informasi, maka guru memanfaatkan sumber-sumberlain selain buku. Hal ini penting sebab penggunaan salah satu sumber tertentu akan membuat pengetahuan siswa terbatas dari satu sumber.

Pendapat tersebut di dukung menurut pendapat Sitepu (2014 : 18), mengemukakan 
bahwa sumber belajar adalah salah satu komponen belajar yang memungkinkan individu memperoleh pengetahuan, kemampuan, sikap, keyakinan, emosi dan perasaan. Sumber belajar memberikan pengalaman belajar dan tanpa sumber belajar maka tidak mungkin dapat terlaksana proses belajar yang baik.

\section{A. PENUTUP}

\section{Simpulan}

Berdasarkan hasil penelitian yang sudah dipaparkan dalam bab IV, maka dapat disimpulkan sebagai berikut.

Sejarah makam Chabib Umar Bin Yusuf Al- Magribi di Desa Candikuning, Bedugul adalah makam seorang tokoh penyebar agama Islam. Makam Chabib Umar Bin Yusuf AlMagribi terletak di atas bukit bedugul yang ditemukan pada tahun 1945-an namun belum diketahui secara jelas mengenai makam ini. Sejak tahun 1967 dimulailah penelitian yang dilakukan oleh Nur Halim dan sejak saat itulah dinyatakan bahwa makam Chabib Umar Bin Yusuf Al- Magribi adalah makam seorang wali yang menyebarkan agama Islam di Bali.

Adapun dampak sosial ekonomi dari makam Chabib Umar Bin Yusuf Al- Magribi bagi masyarakat di Desa Candikuning. Dampak sosial ekonomi yang dimaksud adalah dampak mengenai mata pencaharian masyarakat sekitar makam, pendapatan masyarakat sekitar makam, serta interaksi sosial yang terjadi di dalam masyarakat.

Potensi makam Chabib Umar Bin Yusuf Al- Magribi sebagai sumber belajar sejarah di SMA sangat berpotensi sebagai sumber belajar karena makam ini memiliki nilai historis yang sangat tinggi dalam konteks sejarah. Selain itu nilai pendidikan karakter makam Chabib Umar Bin Yusuf Al- Magribi yang bisa diambil adalah nilai religius, nilai toleransi, nilai disiplin, dan nilai kerja keras.

\section{Saran}

Berdasarkan hasil penelitian yang dilakukan, ada beberapa hal yang penulis sampaikan sebagai sumbang saran terkait dengan hasil penelitian yang telah dilakukan, yaitu :

1. Kepada masyarakat Desa Candikuning agar tetap menjaga kelestarian, kesucian dan kesakralan dari makam Chabib Umar Bin Yusuf Al- Magribi, karena makam Chabib Umar Bin Yusuf AlMagribi sebagai salah satu bagian dari makam wali pitu di Bali yang tidak ternilai harganya dan merupakan aset berharga yang dimiliki Desa Candikuning.

2. Kepada pemerintah dan instansi terkait agar tetap ikut memelihara dan melestarikan keberadaan makam Chabib Umar Bin Yusuf Al- Magribi dan memiliki nilai pendidikan yang tinggi khususnya di bidang sejarah, sosial ekonomi.

3. Kepada peneliti selanjutnya agar senantiasa mengembangkan dan menggali informasi yang belum terungkap dalam penelitian ini agar nantinya dapat melengkapi penelitianpenelitian sebelumnya dan diperolehnya informasi yang utuh tentang keberadaan makam Chabib Umar Bin Yusuf AlMagribi.

4. Bagi guru sejarah, penelitian ini dapat dijadikan sebagai suatu bahan untuk mengembangkan metode-metode belajar yang inovatif yang tidak hanya terbatas pada pembelajaran verbal saja. Hal ini juga ditujukkan dalam pelajaran sejarah yang terkesan membosankan. Melalui penelitian ini, metode-metode belajar baru dapat digunakan sebagai acuan dalam penggunaan sumber belajar sejarah lokal dan melaksanakan kegiatan mengajar belajar secara aktif, kreatif, dan inovatif.

5. Bagi siswa dapat menambah informasi dan pengetahuan tentang arti penting sejarah masa lalu, terutama mengenai makam Chabib Umar Bin Yusuf AlMagribi. 


\section{Daftar Pustaka}

Atmadja, N. B. 2002. "Menajemen Konflik Pada Desa Adat Multi Etnik di Kabupaten Buleleng". IKIP Negeri Singaraja.

Agung S, Leo dan Wahyuni. 2013. Perencanaan Pembelajaran sejarah. Yogyakarta: Penerbit Ombak.

Sanjaya Wina. 2009. Strategi Pembelajaran Berorientasi Standar Proses Pendidikan. Jakarta: Kencana.

Sitepu. 2014. Pengembangan Sumber Belajar. Jakarta: PT Rajagrafindo Persada Sosial Ekonomi Masyarakat. http; Download Portalgaruda. Perkembangan Objek Wisata Goa Kreo Terhadap Kehidupan Sosial Ekonomi Masyarakat (diakses tanggal 5 Desember 2017).

Soekmono. 1981. Pengantar Sejarah Kebudayaan Indonesia I. Yogyakarta: Kanisius.

\section{Sumber Lisan}

Wawancara dengan Kepala Desa I Made Mudita 26 Maret 2019

Wawancara dengan juru kunci Haji Norman (60 tahun) 26 Maret 2019

Wawancara dengan Husen 26 Maret 2019 